\title{
Balıklarda melanomakrofaj merkezleri
}

\section{Melanomacrophage centers in fishes}

\section{A. Erdem Dönmez}

Mersin Üniversitesi Su Ürünleri Fakültesi, Yenişehir Kampüsü, 33169 Mersin edonmez@mersin.edu.tr

How to cite this paper:

Dönmez A.E. (2016). Melanomacrophage centers in fishes (in Turkish with English abstract). Ege Journal of Fisheries and Aquatic Sciences, 33(1): 81-87. doi: 10.12714/egejfas.2016.33.1.12

Öz: Balıklarda doğal bağışıklık sistemi; fiziksel, hücresel ve humoral faktörler ile plazma ve diğer vücut sıvılarında çözünebilen hücresel ve humoral reseptör moleküllerinden oluşmaktadır. Hücresel faktörler fagositik hücreler olan monosit/makrofajlar, nötrofil granülositler ve memelilerdeki NK (natural killer cell) hücrelerine eşdeğer görülen sitotoksik hücreleri içermektedir. Bu hücreler arasında yer alan makrofajlar, balıklarda ve diğer omurgalılarda doğal bağışıklığın indikatör hücreleri olup fagositoz yeteneğine de sahip olduklarından, yangı sonrası onarım, doku yenilenmesi ve yaşı hücrelerin ortadan kaldırıması gibi işlevlere sahiptirler. Melanomakrofaj merkezleri ise pigmentli olmaları nedeniyle histolojik incelemelerde makrofajlardan ayırt edilebilmekte ve aynı zamanda poikiloterm omurgalıların pek çok organında yaygın olarak gözlemlenebilmektedirler. Bu merkezler; makrofaj yığınları, makrofaj birikim odakları ve pigment nodülleri gibi isimlerle tanımlanmış olup heteroterm omurgalıların dokularındaki özgün hücreler olarak kabul edilmektedirler. Bu derlemede söz konusu yapıların balıklarda ait oldukları sistem, ilişkide oldukları hücre ve birimler ile işlevleri hakkında bilgi verilmeye çalışımışıı.

Anahtar kelimeler: Melanomakrofaj merkezleri, balık, immün sistem

\begin{abstract}
Innate immune system in fish consist of physical, cellular and humoral factors along with other cellular and humoral receptor molecules that can be dissolved in plasma and other body fluids. Cellular factors include cytotoxic cells that appear to be equivalent to natural killer cells in mammals, neutrophyl granulocytes and monocyte/macrophages as phagocytic cell. Macrophages which belong to above mentioned cells are indicator cells of innate immunity in fish and other vertebrates having phagocytic ability. Through which they posses functions like repairement after inflammation, tissue regeneration and elimination of old cells. Since melanomacrophage centers are pigmented, they can be easily identified from macrophages in histological examinations and they can also be widely observed in many organs in poikilothermic vertebrates. These centers are named as macrophage stocks, macrophage accumulation centres or pigmented nodules and considered as spesific cells in tissue of heterothermic vertebrates. In this rewiev, the system that these structures are belong to in fish and the cells and their units through which they communicate and functions are discussed.
\end{abstract}

Keywords: Melanomacrophage centers, fish, immune system

\section{Gíriş}

Balıklar bakteri, virüs ve kirletici etkenlerin yoğun olarak bulunabildikleri sucul ortamlarda yaşamlarını sürdüren canlılardır. Bu etkenlerin büyük bir çoğunluğu balıklara zarar verme potansiyeline sahiptir. Balıklar normal koşullar altında doğal bağışıkıı sistemleri aracılığıyla söz konusu potansiyel zararlara karşı koyma yeteneğine sahiptir. Bu sistemde korunma nonspesifiktir ve zararlı etkenin moleküler yapısının ayırt edici bir biçimde tanımlanması gerekli değildir. Ayrıca, bu sistem çok hızlı bir şekilde devreye girmekte ve nispeten de sıcaklık faktöründen bağımsız olarak şekillenebilmektedir (Ellis 2001, Magnadottir 2006, Whyte, 2007). Doğal bağışıklık sistemi sabit ve hareketli hücrelerle vücut sıvılarında çözünebilen çok sayıda molekülden oluşmaktadır. Bu hücreler; sitotoksik hücreler, monosit/makrofajlar ve granülositlerdir (başlıca nötrofil granülositler). Moleküler bileşenler ise; komplement sistemi, pıhtılaşma sistemi, anti proteazlar, metal bağlayıcı proteinler, lektinler, lizozimler, antimikrobiyel peptidler, opsoninler ve sitokinlerdir (Bayne ve Gerwick, 2001). Bağışıklık hücreleri arasında bulunan makrofajlar, fagositoz yeteneğine sahip hücreler olup vücutta homeostazisin sağlanmasında önemli rol oynamaktadırlar. Ayrıca organizmada yaşlanan hücrelerin imhası ve yangı sonrası doku onarımı ile yenilenmesinin sağlanmasında da görev alırlar. Poikiloterm canlılarda makrofajlar, pigment hücreleri ile kümeler oluşturarak pigmentli makrofajlar veya melanomakrofaj merkezleri olarak adlandırılan yapıları oluştururlar (Satizabal, 2013). Bu yapilar lenfoid ve lenfoid olmayan dokularda gözlenebilmektedir. Ayrıca bu yapıların yüksek omurgalılardaki lenfosit ve makrofaj içeren farklı merkezler veya lenf nodüllerinin germinal merkezlerinin ilkel analogları oldukları da 
düşünülmektedir (Agius ve Roberts, 2003). Bu yapıların özellikle son 40 yıllık dönem içerisinde yoğun olarak araştırımasına ve histolojik yöntemlerle incelenmelerine ağılık verilmektedir.

\section{BALIKLARDA IMMÜN SISTEM}

Balıklarda immün sistem; bu sistemi oluşturan organlar, hücresel yapılar ve humoral (sıvısal) faktörlerden meydana gelmektedir. İmmün sistemi oluşturan organlar, lenfoid organlar olarak da tanımlanmaktadır. Balıklarda lenfoid organlar primer ve sekonder olmak üzere ikiye ayrılır. Primer lenfoid organlar; timus, böbrekler ve dalak iken, sekonder lenfoid organlar bağırsaklar, fiziksel bariyerlerler (deri, solungaç) ve karaciğerdir (Zapata vd., 2006, Ocak, 2006, Uribe vd., 2011). Primer lenfoid organlar, lenfositler için kök hücrelerin bulunduğu ve lenfositlerin immün duyarlı hale geldiği yapılardır. Sekonder lenfoid organlar ise antijenlere karşı immün reaksiyonların gerçekleştiği birimlerdir (Bozkurt ve Eren, 2009).

Balıklarda immün sistem farklı alt başlıklar altında incelenmektedir. Spesifik/ nonspesifik, doğal/kazanılmış veya mukozal/sistemik şeklinde bağışıklık sınıflandırmaları söz konusudur. Bu sınıflandırmalar içerisinde en kabul göreni doğal/kazanıımış bağışıklık sınıflandırmasıdır (Bowden, 2008). Doğal bağışıklık çabuk gelişen, spesifik ve nonspesifik olarak patojen etkenlere karşı ortaya çıkan bir savunma sistemidir ve özel bir belleğe sahip değildir. Kazanılmış bağışıklık ise daha spesifiktir ve patojen etkenlere karşı bellek geliştiren ikincil bir savunma sistemidir (Magnadottir 2006, Whyte, S.K., 2007, Suresh, 2009). Doğal bağışıklık sistemi fiziksel, hücresel ve humoral (sıvısal) faktörler ile plazma ve diğer vücut sıvılarında çözünebilen hücresel ve humoral reseptör moleküllerini içermektedir. Fiziksel faktörler; deri, solungaçlar ve sindirim kanalının epitelyal ve mukozal bariyeridir. Hücresel faktörler; önemli oranda fagositik hücreler olan monosit/makrofajlar, nötrofil granülositler ve memelilerdeki NK (natural killer cell) hücrelerine eşdeğer görülen sitotoksik hücrelerdir. Sıvısal faktörler ise; transferrin, antiproteaz, lektin gibi inhibitörlerle, antibakteriyel peptidler, proteazlar, lizozim, C-reaktif proteinler komplement sistemi gibi lizinlerdir (Kav ve Erganis, 2008, Uribe vd., 2011).

\section{MAKROFAJ HÜCRELERI}

Immün sistemin hücresel faktörlerinden olan makrofajlar, balıklarda ve diğer omurgalılarda doğal bağışıklığın indikatör hücreleridir. Memelilerde, kemik iliğindeki hematopoetik kök hücrelerinden uyarlanmakta ve doğal immün yanıtın oluşup sürdürülmesinde görev almaktadırlar (Mulero, 2008, Satizabal 2013, Hodgkinson, 2015). Organizma, stres faktörlerinin etkisi altında iken makrofaj aktivitesinin belirlenmesi en önemli indikatör verilerden biri olarak kabul edilmektedir (Anderson, 1990, Balamurugan vd., 2012). Özellikle balıklardaki myxospora cinsi parazitlerin neden olduğu stres durumlarında bu durum çok belirgin olarak tespit edilmiştir (Haaparanta vd., 1996). Kazanılmış bağışıklık sistemi içerisinde antijen hazırlayıcı hücreler (APCs) olarak da tanımlanmaktadırlar. Dolayısıyla aynı zamanda doğal ve kazanılmış bağışıklık arasında köprü rol üstlenen yapılardır (Joerink vd., 2006). Organlara göre farklı fenotipik ve morfolojik gelişimler göstermektedirler. Karaciğerde Kupffer hücreleri, memeli akciğelerinde alveolar makrofajlar, sinir sistemlerinde mikrogliya hücreleri, kemik dokuda osteoklastlar ve dalakta spesifik makrofajlar olarak yer almaktadırlar (Forlenza vd., 2011). Balıklarda bu hücreler, fagositik miyeloid hücreleri gibi yaraların onarılmasında, tümörler dahil olmak üzere yabancı etkenlerin, virüslerin ve diğer işgalci patojenlerin belirlenmesi ve elemine edilmesinde önemli bir rol oynamaktadırlar. Dahası bu hücreler nötrofil granülositlerle birlikte patojen etkenleri tanıyıp yıkımlayan, hücresel iletişim ve aktivasyonu sağlayan, kazanılmıs immün yanıtın başlatıması ve sonrasında yangısal yanıtın ve doku onarımının oluşmasını sağlayan pek çok biyoaktif molekülün üretilmesinden sorumludurlar (Katzenback vd., 2012). Makrofajların önemli bir işlevi de interlökin (Ils) adı verilen farklı sitokinlerin, interferonlar ile tümör nekroz faktörlerinin ve yangısal prostanoidlerin üretimi aracilığıyla immün yanıta katkı sağlamasıdır (Mulero vd., 2008). Balık makrofajları aynı zamanda yine bakterisit etkili nitrik oksit de taşımaktadır. Bu hücrelerin aktivasyonları, farklı yollarla olmakla birlikte, genellikle antijenler tarafından uyarılmış olan T lenfositlerce üretilmiş ve gama interferon olduğu düşünülen aktivasyon etkenleri yoluyla gerçekleşmektedir (Ellis, 1999). Balıklarda makrofajların fagositik, mikrobisitik ve salgı (sitokinler) aktivasyonları sadece antijenik faktörler ile değil nöroendokrinik yollarla da sağlanmaktadır (Verburg Van Kemenade vd., 1994). Makrofajların sayı, büyüklük ve pigment içerikleri; balık sağlığının bozulduğu durumlarda, stres koşulları altında ve çevresel kontaminanatlara tepki olarak değişiklikler göstermektedir. Özellikle çevresel kirleticilerin etkisinin tespitinde ve bakteriyolojik enfeksiyonlarda immünolojik biyobelirteçler arasında, melanomakrofaj merkezlerinin büyüklükleri, sayıları ve histopatolojik görünümleri ile kemotaksi, fagositoz, pinositoz ve kemiluminesans gibi makrofaj aktivitelerinin düzeyleri önemli parametreler olarak değerlendirilmektedir (Van der Oost vd., 2003, Faccioli vd., 2014, Ledic-Neto vd., 2014).

\section{MELANOMAKROFAJ MERKEZLERI}

Melanomakrofaj merkezleri; farklı araştırmacılar tarafından; makrofaj merkezleri, makrofaj yığınları, makrofaj birikim odakları ve pigment nodülleri gibi isimlerle tanımlanmış, heteroterm omurgalıların dokularındaki özgün hücrelerdir (Leknes, 2007, Clemente vd., 2010). Pigmentli olmaları nedeniyle histolojik incelemelerde makrofajlardan ayırt edilebilmekte ve aynı zamanda poikiloterm omurgalıların pek çok organında yaygın olarak gözlemlenebilmektedirler (Kranz, 1989, Ferreira, 2011). Elektronmikroskobik incelemelerde fibroblast hücrelerinden oluşan ince bir kapsülle sarılı oldukları ve yalancı ayak benzeri uzantılara sahip, eksantrik yerleşimli çekirdekçikleri bulunan ve sitoplazmalarında çok farklı sayıda ve elektron yoğunluğuna sahip granüller taşıyan, düzensiz şekilli hücreler oldukları tespit edilmiştir (Abdel Aziz vd., 2010). 
Çoğunlukla kümeler halinde bulunmakla beraber, daha düşük oranda gruplar halinde veya tek tek de gözlemlenebilmektedirler. (Satizabal ve Magor, 2015).

Melanomakrofaj merkezleri balıklarda retiküloendoteliyal sistemin bir parçası olarak tanımlanmakta olup, hematopoetik organlar olan dalak (Leknes, 2007, Kurtovic vd., 2008, Satizabal ve Magor, 2015) ve böbreklerin stromalarında (Camargo ve Martinez, 2007, Leknes, 2007, Kurtovic vd., 2008 Timur vd., 2011, Ekele ve Callistus, 2014, Satizabal ve Magor 2015), amfibiler, sürüngenler ve yine bazı balık türlerinde de karaciğer (Stentiford vd., 2003, Camargo ve Martinez, 2007 Dönmez ve Korkmaz, 2012) dokusunda bulunabilmektedirler. Balıklarda ayrıca timus, bağırsak submukozası, solungaçlar, beyin ve gonadlarda da yer aldıklarına dair bulgulara rastlanmaktadır (Şekil 1).

\section{Melanomakrofaj merkezlerinin işlevleri}

Melanomakrofaj merkezlerinin kronik yangısal lezyonlarda ve ovaryumlardaki atrezi süreçlerinde gözlendikleri bildirilmiştir. Hatta kronik yangılarda melanin içeren melanomakrofa merkezlerinin miktarındaki artışın spesifik bir bulgu olduğu da belirtilmektedir (Wolke vd., 1985, Haaparanta vd., 1996, Jansson, 2002). Bu merkezlerin endojen (melanin, lipofuksin, seroid, hemosiderin pigmentleri) ve ekzojen (metaller, biyolojik aktif moleküller) pek çok materyalin yıkımlanması, detoksifikasyonu ve yenilenmesinde görev aldıkları farkl araştırmalarda belirtilmiştir (Kurtovic vd., 2008, Passantino vd., 2014). Bu görevler; fagositoz materyalleri, materyallerin içerdikleri katyonlar, fagosite edilen hücre yıkıntıları ve immünolojik reaksiyonlara göre değişiklikler göstermektedir (Ribeiro vd., 2011). Özellikle histokimyasal çalışmalar sonucunda, hemoglobinin parçalanma ürünü olan demir içeriğ nedeniyle, memelilerin immün sistemindeki demir ve demiri bağlayan proteinlerle ilişkisi olan lenf nodüllerinin eşdeğeri olarak kabul edilmişlerdir. Ayrıca yüksek omurgalılardak lenfosit ile makrofaj içeren farklı merkezlerle, germinal merkezlerin ilkel analogları oldukları da düşünülmektedir. Bu merkezler, hemolitik hastalıklarda demiri tutma ve hapsetme görevine sahip olmakla birlikte, antijenlere bağlanma ve lenfositlere taşıma, potansiyel toksik materyallerin ve hücrese yıkım ürünlerinin ayrıştırılması gibi görevleri de yerine getirmektedir. Ayrıca hücre içi yerleşen dirençli bakterileri hapseden odaklar olarak da görev yapmaktadırlar. Bunun yanı sıra eritrosit fagositozunun arttığı durumlarda, dalakta demir içeren melanomakrofaj merkezlerinin arttığı da belirlenmiştir. Dalağı çıkarılmış balıklarda bu görevi böbreklerde yer alan melanomakrofaj merkezlerinin devraldığı tespit edilmiştir (Agius, 1979, Agius ve Roberts, 2003).

Melanomakrofajların yıkımlayıcı etkilerine ek olarak antijenantikor kompleksi oluşturması bakımından, uzun süreli antijen koruyucu etkisinin olduğundan da söz edilebilir. Anterior böbrekte yer alan melanomakrofaj merkezleri tipik bir şekilde damarlara bitişik olarak konumlanmışlardır (Satizabal ve Magor, 2015). Dolaşımda bulunan bir miktar lenfosit hücresinin de melenomakrofaj kümelerinin olduğu bölgelere göç ettikleri, dolayısıyla immün yanıtın gelişmesinde antijen ile bağışıklık hücreleri arasında lokal bir etkileşim sağlanmasına katkıda bulundukları düşünülmektedir. Ayrıca lenfoid hücrelerle antijen arasında ilişki gelişimine yardımcı olmak amacıyla antijenlerin uzun süre alıkonulmasını sağlayan merkezler oldukları da tartışılmaktadır (Lamers ve De Haas, 1985). Bu nedenle immün hafıza oluşumu açısından da bu merkezlerin dolaylı bir etkinliğe sahip oldukları düşünülmektedir (Manrique vd., 2014)

\section{Melanomakrofaj Merkezlerinin Pigment İçerikleri}

Melanomakrofajların morfolojik görünümleri, büyüklükleri ve hücresel içerikleri teleostlarda farklı tür ve dokularda değişkenlikler göstermektedir. Bu farklılıkların yaş, hastalıklar, açlık, stres ve sudaki yabancı maddelerden kaynaklandığına dair düşünceler ileri sürülmektedir (Leknes, 2007, Dabrowska vd., 2012). Melanomakrofaj merkezleri dört farklı tipte pigment içermektedir. Bu pigmentler; melanin, lipofuksin (lipojenik bir pigment) ve seroid ile hemosiderin (hematojen bir pigment)'dir (Schwindt vd., 2006). Adlandırılmalarının aksine en fazla içerdikleri pigment lipofuksindir. Lipofuksin veya seroidler; $\mathrm{E}$ vitamini yetersizliğinde bölünemeyen hücrelerde biriken doymamış yağ asitlerinin peroksidasyonu ile ortaya çıkan bozunmamış metabolitlerdir. Memelilerde yaş ilerlemesine bağı olarak ortaya çıkmaktadırlar (Yin, 1996, Grune vd., 2001). Balıklarda lipofuksin birikimi, yaşlı veya apoptotik eritrosit ve lökosit hücrelerinin tutulması veya otofajisi ile gerçekleşir. Bu durum memelilerdekine oranla balıklarda daha belirgindir. Çünkü hücre membranlarında bulunan doymamış yağ asitleri düzeyi balıklarda memelilere göre daha yüksek ve $E$ vitamini düzeyleri ise daha düşük düzeydedir. İkinci önemli pigment ise farklı ekzojen kaynaklardan türevlendiği veya hücre içinde şekillendiği düşünülen melanindir. Melaninin fagosite edilmiş hücre membranlarının yıkımlanması sırasında ortaya çıkan serbest radikalleri nötralize etmede önemli bir role sahip olduğu ve hidrojen peroksit gibi antimikrobiyel bileşiklerin üretiminde rol oynadığı düşünülmektedir (Solano, 2014). Hemosiderin pigmenti ise hemoglobinin yıkımlanması sırasında demirin hücre içi depolanmasındaki en önemli pigmenttir ve demirin geri dönüşümünde bir ara adım olarak hizmet etmektedir. Bu pigmentlerin varlığı, tür farklılığına ve bireylerin doku ve hücrelerinde farklı fizyolojik koşullara bağlı olarak değişkenlikler göstermektedir (Satizabal ve Magor, 2015). Melanin pigmenti gümüş nitrat boyaya yüksek duyarlılık gösterdiğinden, histolojik incelemelerde Masson-Fontana boyama yöntemi ile rahatlıkla tespit edilebilmektedir. Lipofuksin, daha çok Hematoksilen-eozin boyama yöntemi ile gözlemlenebilmektedir fakat şeker içeriği nedeniyle PAS (Periodic Acid Schiff) yönteminin de bu pigment için uygun olacağı belirtilmektedir (Culling, 1974). Hemosiderin ise en rahat Perl's boyama yöntemi ile görüntülenebilmektedir (Ferreira, 2011)

Prochilodus argenteus türü balıklarda yapılan bir araştırmada, melanomakrofaj granülleri içerisinde hemosiderin pigmentinin, karaciğer dokusunda dalak dokusuna göre daha sıklıkla ortaya çıktığı tespit edilmiştir. Bunun yanısıra lipofuksin pigmentinin de yoğun olarak bulunduğu, fakat melanin 
pigmentine göre çok daha düşük oranlarda rastlanıldığ belirlenmiştir. Ayrıca melanomakrofaj merkezlerinin sınırlarının, karaciğer dokusunda daha düzenli, dalak dokusunda ise daha polimorf şekillerde ortaya çıktığı gözlenmiştir (Ribeiro vd., 2011).

\section{Melanomakrofaj merkezlerinde oluşan değişiklikler}

Doğal balık populasyonlarında rastlanan hastalıkların izlenmesinde melanomakrofaj merkezlerinin de incelenmesinin gerektiği belirtilmektedir (Schwindt vd., 2006). Lymphocystis, Ichthyophonus ve Myxobolus pseudodispar etkenleri gibi yoğun doku hasarının ortaya çıktığı kronik yangıların geç evrelerinde immün reaksiyon olarak melanomakrofaj merkezlerinin ortaya çıktığı tespit edilmiştir. Bu merkezler yersiniozis ve vibriozis gibi hastalıklarda da önemli bir rol oynamaktadır. Her iki enfeksiyonda da özellikle kronikleşen olgularda ciddi hemolitik aneminin gelişmesi ve viral nervöz nekroz (Nodavirüs) hastalığında çok miktarda hemosiderin pigmentinin ortaya çıkması bu merkezlerin oluşmasına neden olmaktadır (Khalil vd., 2011, Kim ve Faisal, 2011, Gregori vd., 2014). Bunun yanı sıra sayılarının artışında hayvanlarda aç kalmanın neden olduğu kaşektik durumların da etkili olduğu düşünülmektedir (Hur vd., 2006, Harper ve Wolf, 2009). Salmo salar türü alabalıklarda Aeromonas salmonicida etkenine karşı uygulanan aşılama sonrasında dalak ve böbrek dokusunda melanomakrofaj merkezlerinin artış gösterdiği tespit edilmiştir. $\mathrm{Bu}$ artışa, melanomakrofaj merkezlerinde uzun süreli antijen tutulumu sonrasında immün kompleks oluşumunun ve antikor düzeylerinin artmasının yol açtığı ileri sürülmektedir (Manrique vd., 2014).

Boya ve farmasötik sanayisinde kullanılan bir madde olan fenilhidrazin'in uygulandığı Carassius auratus'larda melanomakrofaj merkezlerinin sayılarında artışlar olduğu belirlenmiştir (Herraez ve Zapata, 1986). Meksika Körfezi'nde, farklı 7 balık türünün dalak dokularının mikroskobik incelemelerinde $\mathrm{mm}^{2}$ alanda 40 'ın üzerinde melanomakrofaj kümesinin varlığının, hipoksik ortam veya sedimentte kontaminasyon varığı ile ilişkilendirilebileceği kabul edilmiştir (Fournie vd., 2001). Araştırmalar, bu merkezlerin çoğunlukla artış bazen de azalış gösterdiklerini ortaya koymuştur. Artışın genellikle, hücresel yıkıntıları kaldırmak için hücresel savunma sistemi içerisinde fagositik aktivite artışına bağlı olarak ortaya çıktığı düşünülmektedir (Ghosh ve Homechaudhuri, 2012, Ledic-Neto vd., 2014).

\section{Biyobelirteç olarak melanomakrofaj merkezleri}

Çevresel kirliliğin etkisinde kalan balıklar, immün sistem aktivitesi ya da nonspesifik savunma sistemleri yoluyla adaptasyon sağlamaya çalışırlar. Son yıllarda yapılan araştırmalar, histolojik bulguların su kalitesi değişikliklerinin balıklarda oluşturduğu fizyolojik stresin belirlenmesinde biyobelirteç parametreler olduğunu göstermektedir (Stentiford vd., 2003, Osman vd., 2010, Lieel vd., 2013). Çevresel kirleticilerin etkisi, doğrudan ölümlere neden olsa da subletal etkileri de çok yaygındır. Kontamine sularda çeşitli parazit ve hastalık etkenlerinin görülme sıklığının da arttığı bildirilmiştir
(Marcogliese, 2005, Sures, 2008). Balıklarda farklı kirleticilerin etkisindeki su ortamlarında, çeşitli ksenobiyotik metabolize edici enzimlerin artışı da söz konusudur (Velkova-Jordanosko vd., 2008, Osman vd., 2010). Yalnız bu enzimler nispeten sınırlı sayıdaki kimyasal kirleticiye karşı ortaya çıkmaktadır. Bu nedenle spesifik olmayan çevresel kontaminasyonlarda balık sağlığını izlemek açısından daha etkin ve uygulanabilir yöntemlere gereksinim duyulmaktadır. Melanomakrofaj kümeleri çevresel değişiklikler, stres ve yabancı partiküllerin eleminasyonu bakımından biyobelirteç yapılar olarak kabul edilmektedir (Balamurugan vd., 2012, Sakthivel vd., 2012). İçerdikleri hücre içi granüllerin farklılıkları sayesinde; protein sentezi, kalsiyum depolanması, demir metabolizması ve detoksifikasyon süreçleri gibi hücresel metabolik faaliyetler hakkında önemli bilgilerin sağlanabileceği yapılardır. Ayrıca içerdikleri fosfor granülleri aracılığıyla bazı iz metalleri de kapsayan farklı kimyasal maddelerin tespiti açısından da özel birimler olarak değerlendirilmektedirler (Ribeiro vd., 2011).

Melanomakrofaj merkezlerinin metrik özelliklerinin (sayı, büyüklük ve dokuyu işgal yüzdeleri) kirleticilerin yoğun olduğu bölgelerde farklılıklar gösterdiğine dair araştırmalar da bulunmaktadır (Rabitto vd., 2005, Suresh, 2009, Ali vd., 2014). ABD Çevre Koruma Bakanlığının, çevresel izleme değerlendirme ve çevresel jeolojik ölçümler biyoizleme programlarında incelenmesi gereken önemli parametrelerden birisi olarak kabul edilmektedir (Facey vd., 2005)

\section{SONUÇ VE ÖNERILER}

Balıklar, yaşadıkları ortam nedeniyle karada yaşayan organizmalara göre çok farklı antijenik etkenlerle karşı karşıya gelebilen canlılardır. Aynı zamanda sucul ortamlarda oluşan pek çok farklılaşma da balıkları doğrudan etkileyebilme potansiyeline sahiptir. Ani sıcaklık değişimleri, su kalitesinde bozulmalar ve sucul ortam kirleticileri balık sağlığını etkileyebilmekte ve yüksek oranda ölümlerle seyreden büyük popülasyon kayıplarına neden olabilmektedir. Bu tür nedenlerle, balıklar üzerinde yapılan bilimsel araştırmalar da özellikle son yıllarda artış göstermektedir. Çeşitli biyokimyasal, hücresel ve fizyolojik sistemler arasında bazı immün reaksiyonlar, biyolojik etkilerin izlenmesi bakımından indikatör parametreler olarak öne çıkmaktadır. Melanomakrofaj merkezleri veya pigmentli makrofaj yığınları olarak tanımlanan yapılar da, nonspesifik hücresel yanıtın belirlenmesi ve çevresel kontaminantların oluşturduğu fizyolojik stresin tespiti bakımından biyoindikatör parametre olarak kabul edilmektedir. İmmün sistemdeki işlevlerine dair bilgiler ise hala araştırmacılar tarafından tartışımaktadır. Melanomakrofaj kümeleri, histoloji alanında balıkların lenfoid organlarında oluşmakta olan ayırt edici organize hücre kümeleşmelerinden en fazla araştııılanı olmakla beraber farklı organlardaki görevleri hakkında araştırmaların sayılarının nispeten az olduğu belirtilmektedir. $\mathrm{Bu}$ nedenle özellikle günümüzde sucul ortamlara karışan kirletici etkenlerin yoğunlaşması ve patojen etkenlerin balıklara bulaşma oranının artması bu yapıların fonksiyonlarına ilişkin daha fazla bilgiye gereksinim duyulduğunu düşündürmektedir. 


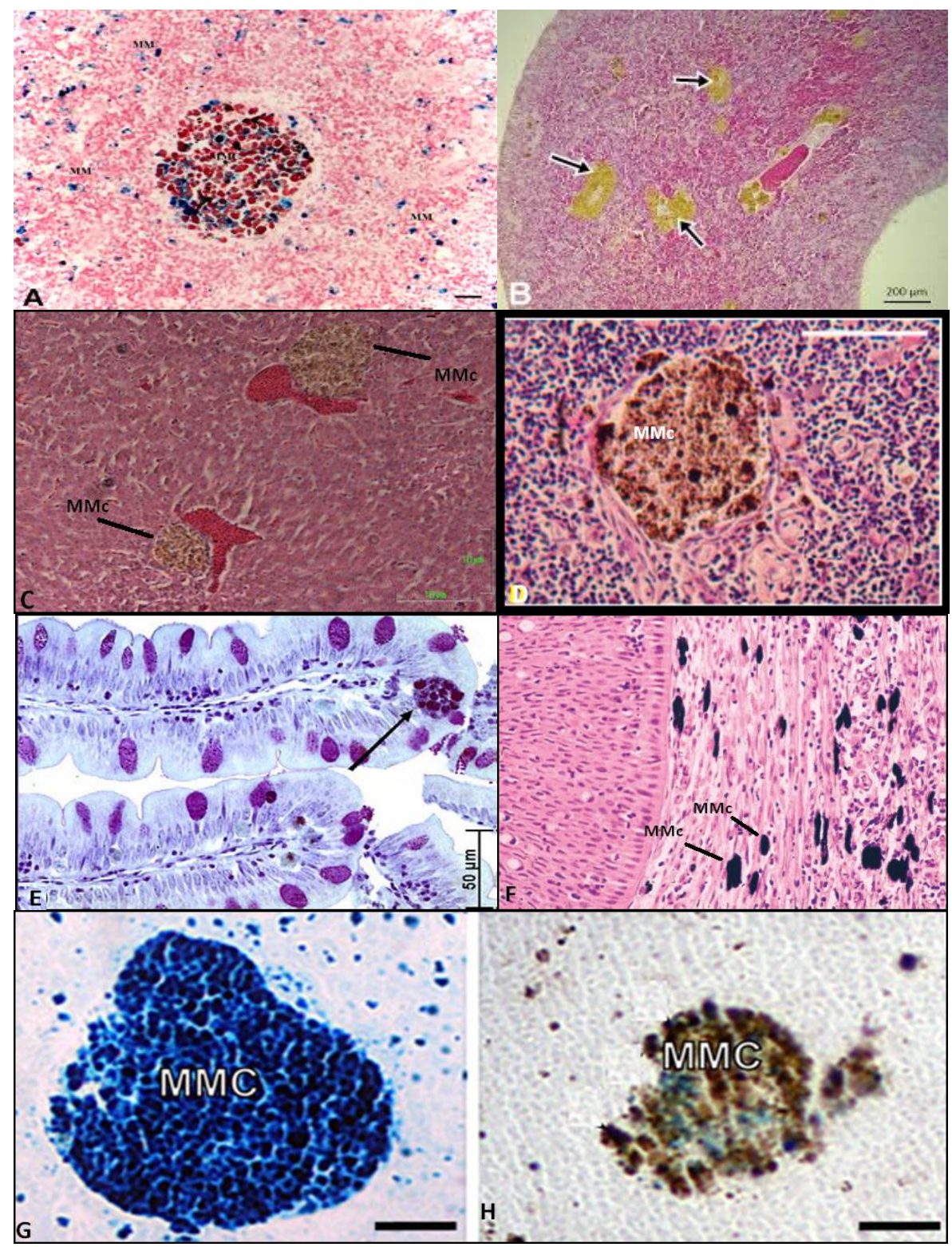

Şekil 1. Farklı balık türlerinin lenfoid organlarında tespit edilmiş melanomakrofaj merkezlerinin görünümü A) Oreochromis niloticus, dalak, Pearl's, x400 (Manrique vd., 2014) B) Oreochromis niloticus, böbrek, hematoksilen-eozin, bar=200 $\mu \mathrm{m}$ (Ledic-Neto vd., 2014) C) Liza ramada, karaciğer, hematoksilen-eozin, bar=10 um (Dönmez ve Korkmaz, 2012) D) Epinephelus malabaricus, timus, hematoksilen-eozin, bar=10 $\mu \mathrm{m}$ (Lin vd., 2005)

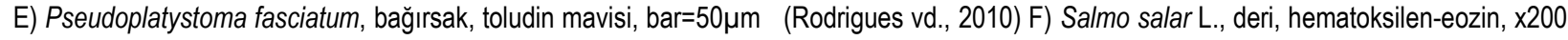

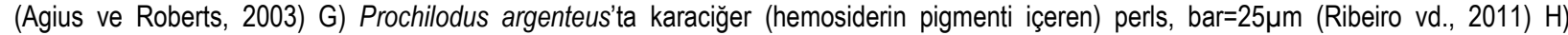
Prochilodus argenteus'ta dalak (lipofuksin veya seroid pigmenti içeren), perls, bar=25 um (Ribeiro vd., 2011).

Figure 1. Melanomacrophage centers have been identified of lymphpoid organs of different fish species A) Oreochromis niloticus, spleen, Pearl's, x400 (Manrique et al., 2014) B) Oreochromis niloticus, kidney, hematoxylin-eosin, scale bar=200 $\mu \mathrm{m}$ (Ledic-Neto et al., 2014) C) Liza ramada,

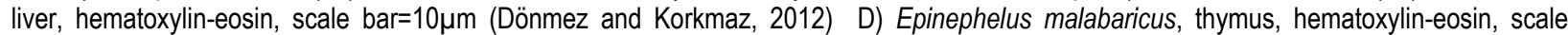
bar=10 $\mu \mathrm{m}$ (Lin et al., 2005) E) Pseudoplatystoma fasciatum, intestine, toluidin blue, scale bar=50 $\mathrm{mm}$ (Rodrigues vd., 2010) F) Salmo salar L., skin, hematoxylin-eosin, x200 (Agius ve Roberts, 2003) G) Prochilodus argenteus, liver (exhibiting hemosiderin), Perl's, scale bar=25 $\mu m$ (Ribeiro vd., 2011) H) Prochilodus argenteus, spleen (exhibiting lipofuscin and/or ceroid), Perl's, scale bar=25 $\mu$ m (Ribeiro vd., 2011). 


\section{KAYNAKÇA}

Abdel Aziz, E.H., Abdu, S.B.S., Ali, T.E. \& Fouad, H.F. (2010). Haemopoiesis in the head kidney of tilapia, Oreochromis niloticus (Teleostei: Cichlidae) a morphological (optical and ultrastructural) study. Fish Physiology and Biochemstry, 36: 323-336. doi: 10.1007/s10695-008-9297-z.

Agius, C. (1979). The role of melano-macrophage centres in iron storage in normal and diseased fish. Journal of Fish Diseases, 2: 337-343. doi: 10.1111/j.1365-2761.1979.tb00175.x.

Agius, C. \& Roberts, R.J. (2003). Melano-macrophage centres and their role in fish pathology. Journal of Fish Diseases, 26: 499-509. doi: 10.1046/j.1365-2761.2003.00485.x

Ali, A.O., Hohn, C., Allen, P.J., Ford, L., Dail, M.B., Pruett, S. \& Petrie-Hanson L. (2014). The effects of oil exposure on peripheral blood leukocytes and splenic melano-macrophage centers of Gulf of Mexico fishes. Marine Pollution Bulletin, 79: 87-93. doi: 10.1016/j.marpolbul.2013.12.036.

Anderson, D.P. (1990). Immunological indicators: effects of environmental stress on immune protection and disease outbreaks. American Fisheries Society Symposium Series, 8: 38-50

Balamurugan, S., Deivasigamani, B., Kumaran, S., Sakthivel, M., Rajsekar, M. \& Priyadharsini, P. (2012). Melanomacrophage centers aggregation in $P$ lineatus spleen as bio-indicator of environmental change. Asian Pacific Journal of Tropical Disease, 2(2): 635-638. doi: 10.1016/S2222-1808(12)60235-7.

Bayne, C.J. \& Gerwick, L. (2001). The acute phase response and innate immunity of fish. Developmental \& Comparative Immunology, 25(8-9) 725-743. doi:10.1016/S0145-305X(01)00033-7.

Bowden, T.J. (2008). Modulation of the immune system of fish by their environment. Fish \& Shellfish Immunology, 25: 373-383. doi:10.1016/j.fsi.2008.03.017.

Bozkurt, M. \& Eren, Ü. (2009). Lymphoid organs of fishes (in Turkish with English abstract). Veteriner Hekimler Derneği Dergisi, 80(2): 13-18.

Camargo, M.M.P. \& Martinez, C.B.R. (2007). Histopathology of gills, kidney and liver of a Neotropical fish caged in an urban stream. Neotropical Ichthyology, 5(3): 327-336. doi: 10.1590/S1679-62252007000300013.

Clemente, Z., Busato, R.H., Oliveira Ribeiro, C.A., Cestari, M.M., Ramsdorf, W.A., Magalha, V.G., Wosiack, A.C. \& Silva de Assis, H.C. (2010) Analyses of paralytic shellfish toxins and biomarkers in a southern Brazilian reservoir. Toxicon, 55, 396-406 doi:10.1016/j.toxicon.2009.09.003

Culling, C.F.A. (1974). Handbook of Histopathological and Histochemical Techniques. Michigan: Butterworth-Heinemann.

Dabrowska, H., Ostaszewska, T., Kamaszewski, M., Antoniak, A., NaporaRutkowski, L., Kopko, O., Lang, T., Fricke, N.F. \& Lehtonen, K.K. (2012) Histopathological, histomorphometrical and immunohistochemical biomarkers in flounder (Platichthys flesus) from the southern Baltic Sea. Ecotoxicology and Environmental Safety, 78, 14-21. doi:10.1016/j.ecoenv.2011.10.025

Dönmez, A.E. \& Korkmaz, C. (2012). Liver histopathology of thinlip mullet (Liza ramada) captured from Karaduvar harbor (Mersin, TURKEY) (in Turkish with English abstract). In Y. Vardar (Ed.), 21. Ulusal Biyoloji Kongresi 2012 (s. 1011-1012). İzmir, Türkiye: Bildiri Kitabı.

Ekele, I. \& Callistus, N.U. (2014). The kidney micromorphology of the farmed juvenile african catfish (Clarias gariepinus B.) from Eastern Nigeria. Global Journal of Medicine Researches and Studies, 1(4): 97-102.

Ellis, A.E. (1999). Immunity to bacteria in fish. Fish \& Shellfish Immunology, 9 291-308. doi: 10.1006/fsim.1998.0192.

Ellis, A.E. (2001). Innate host defense mechanisms of fish against viruses and bacteria. Developmental \& Comparative Immunology, 25(8-9): 827-39. doi: 10.1016/S0145-305X(01)00038-6

Faccioli, C.K., Chedid, R.A., Bombonato, M.T.S., Vicentini, C.A. \& Vicentin I.B.F. (2014). Morphology and histochemistry of the liver of Carnivorous fish Hemisorubim platyrhynchos. International Journal of Morphology, 32(2): 715-720. Doi: 10.4067/S0717-95022014000200055

Facey, D.E., Blazer, V.S., Gasper, M.M. \& Turcotte, C.L. (2005). Using fish biomarkers to monitor improvements in environmental quality. Journal of Aquatic Animal Health, 17: 263-266. doi: 10.1577/H04-055.1

Ferreira, C.M.H. (2011). Can fish liver melanomacrophages be modulated by xenoestrogenic and xenoandrogenic pollutants? Experimental studies on the influences of temperature, sex, and ethynylestradiol, using the platyfish as the model organism. Master of Science Thesis, Universidade de Porto, Institute of Biomedical Sciences Abel Salazar, $53 \mathrm{p}$.

Forlenza, M., Fink, I.R., Raes, G. \& Wiegertjes, G.F. (2011). Heterogeneity of macrophage activation in fish. Developmental and Comparative Immunology, 35: 1246-1255. doi: 10.1016/j.dci.2011.03.008

Fournie, J.W., Summers, J.K., Courtney, L.A., Engle, V.D. \& Blazer, V.S. (2001). Utility of splenic macrophage aggregates as an indicator of fish exposure to degraded environments. Journal of Aquatic Animal Health, 13: 105-116. doi: 10.1577/1548-8667(2001)013<0105:uosmaa>2.0.co;2.

Ghosh, R. \& Homechaudhuri, S. (2012). Transmission electron microscopic study of renal haemopoietic tissues of Channa punctatus (Bloch) experimentally infected with two species of aeromonads. Turkish Journal of Zoology, 36(6): 767-774. doi:10.3906/zoo-1112-7.

Gregori, M., Miragliotta, V., Leotta, R., Cecchini, S., Prearo, M. \& Abramo, F. (2014). Morphometric evaluation of interrenal gland and kidney macrophages aggregates in normal healthy rainbow trout (Oncorhynchus mykiss) and after bacterial challenge with Yersinia ruckeri. Veterinary Medicine International, 210625: 7. Doi: 10.1155/2014/210625.

Grune, T., Shringarpure, R., Sitte, N. \& Davies, K. (2001). Age-related changes in protein oxidation and proteolysis in mammalian cells. Journals of Gerontology Biological Sciences, 56 (11): 459-67.

Haaparanta, A., Valtonen, E.T., Hoffmann, R. \& Holmes, J. (1996). Do macrophage centres in freshwater fishes reflect the differences in water quality? Aquatic Toxicology, 34: 253-272. doi: 10.1016/0166-445X(95)00042-3.

Harper, C. \& Wolf, J.C. (2009). Morphologic Effects of the Stress Response in Fish. Ilar Journal, 50(4): 387-396

Herraez, M.P. \& Zapata, A.G. (1986). Structure and function of the melanomacrophage centres of the goldfish Carassius auratus. Veterinary Immunology and Immunopathology. 12(1-4): 117-26.

Hodgkinson, J.W., Grayfer, L. \& Belosevic, M. (2015). Biology of Bony Fish Macrophages. Biology, 4: 881-906. doi:10.3390/biology4040881

Hur, J.W., Woo, S.R., Jo, J.H \& Park, I.S. (2006). Effects of starvation on kidney melano-macrophage centre in olive flounder, Paralichthys olivaceus (Temminck and Schlegel). Aquaculture Research, 37: 821-825.

Jansson, E. (2002). Bacterial kidney disease in salmonid fish. Doctoral thesis, Swedish University of Agricultural Sciences Uppsala, $52 \mathrm{p}$.

Joerink, M., Ribeiro, C.M.S., Stet, R.J.M., Hermsen, T., Savelkoul, H.F. J., Wiegertjes \& G.F. (2006). Head kidney-derived macrophages of Common Carp (Cyprinus carpio L.) show plasticity and functional polarization upon differential stimulation. Journal of Immunology, 177: 61-69. doi: 10.4049/jimmunol.177.1.61.

Katzenback, B.A., Katakura, F. \& Belosevic, M. (2012). Regulation of teleost macrophage and neutrophil cell development by growth factors and transcription factors. In : New Advances and Contributions to Fish Biology, H.Türker (Ed.), InTech, Rijeka, Croatia, pp. 97-149.

Kav, K. \& Erganis, O. (2008). Immune system of fishes (in Turkish with English abstract). Atatürk Üniversitesi Veteriner Bilimleri Dergisi, 24(1): 97-106.

Khalil, R.H., El-Hofy, H.R. \& Mahfouz, N.B. (2011). Contribution to Vibriosis in Cultured Eels (Anguilla anguilla). Journal of American Science, 7(12): 101110 
Kim, R. \& Faisal, M. (2011). Emergence and resurgence of the viral hemorrhagic septicemia virus (Novirhabdovirus, Rhabdoviridae Mononegavirales). Journal of Advanced Research, 2(1): 9-23. doi:10.1016/j.jare.2010.05.007.

Kranz, H. (1989). Changes in splenic melano-macrophage centres of dab Limanda limanda during and after infection with ulcer disease. Diseases of Aquatic Organisms, 6: 167-173.

Kurtovic, B., Teskeredzic, E. \& Teskeredzic, Z. (2008). Histological comparison of spleen and kidney tissue from farmed and wild European sea bass (Dicentrarchus labrax L.). Acta Adriatica, 49(2): 147-154.

Lamers, C.H.J. \& De Haas, M.J.H. (1985). Antigen localization in the lymphoid organs of carp (Cyprinus carpio). Cell and Tissue Research. 242: 491-498.

Ledic-Neto, J., Dotta, G., Garcia, P., Brum, A., Gonçalves T.E.L \& Martins, M.L. (2014). Haematology and melanomacrophage centers of Nile tilapia fed supplemented diet with propolis. Acta Scientiarum Biological Sciences, 36(3): 263-269. doi: 10.4025/actascibiolsci.v36i3.22024.

Leknes, I.L. (2007). Melano-macrophage centres and endocytic cells in kidney and spleen of pearl gouramy and platyfish (Anabantidae, Poeciliidae: Teleostei), Acta Histochemica, 109: 164-168. doi:10.1016/j.acthis.2006.10.003.

Liebe, S., Tomotake, M.E.M. \& Ribeiro, C.A.O. (2013). Fish histopathology as biomarker to evaluate water quality. Ecotoxicology and Environmental Contamination, 8(2), 09-15.

Lin, H.T., Lin, H.Y. \& Yang, H.L. (2005). Histology and histochemical enzymestaining patternsof major immune organs in Epinephelus malabaricus. Journal of Fish Biology, 66: 729-740. doi:10.1111/j.1095-8649.2005.00635.x.

Magnadottir, B. (2006). Innate immunity of fish (overview). Fish and Shellfish Immunology, 20: 137-151.

Manrique, W.G., Sa Silva Claudiano, G., Petrillo, T.R., Pardi de Castro, M., Pereira Figueiredo, M.A., De Andrade Belo, M. A., Engracia De Moraes J.R. \& Ruas De Moraes F. (2014). Response of splenic melanomacrophage centers of Oreochromis niloticus (Linnaeus, 1758) to inflammatory stimuli by BCG and foreign bodies. Journal of Applied Ichthyology, 30(5): 1-6. doi: 10.1111/jai.12445.

Marcogliese, D.J. (2005). Parasites of the superorganism: Are they indicators of ecosystem health? International Journal for Parasitology, 35: 705-716.

Mulero, I., Sepulcre, M.P., Roca, F.J., Meseguer, J., Garcia-Ayala, A. \& Mulero, V. (2008). Characterization of macrophages from the bony fish gilthead seabream using an antibody against the macrophage colony-stimulating factor receptor. Developmental and Comparative Immunology, 32: 1151 1159. doi:10.1016/j.dci.2008.03.005

Ocak, F. (2006). Lenfoid organs and the properties of immune system in fish (in Turkish with English abstract). Erciyes Üniversitesi Veteriner Fakültesi Dergisi, 3(1): 61-66.

Osman, A.G.M., Abd El Reheem, A.M., AbuelFadl, K.Y. \& GadEl- Rab, A.G. (2010). Enzymatic and histopathologic biomarkers as indicators of aquatic pollution in fishes. Natural Science, 2(11): 1302-1311.

Passantino, L., Santamaria, N., Zupa, R., Pousis, C., Garofalo, R., Cianciotta A., Jirillo, E., Acone, E. \& Corriero, A. (2014). Liver melanomacrophage centres as indicators of Atlantic bluefin tuna, Thunnus thynnus L. wellbeing. Journal of Fish Diseases, 37: 241-250. doi:10.1111/jfd.12102.

Rabitto, I.S., Alves Costa, J.R.M., Silva de Assis, H.C., Pelletier, E., Akaishi, F.M., Anjos, A., Randi, M.A.F. \& Oliveira Ribeiro, C.A. (2005). Effects of dietary $\mathrm{Pb}(\mathrm{II})$ and tributyltin on neotropical fish, Hoplias malabaricus: histopathological and biochemical finding. Ecotoxicology and Environmental Safety 60: 147-15. doi:10.1016/j.ecoenv.2004.03.002.

Ribeiro, H. J., Procópio, M.S., Gomes, J.M.M., Vieira, F.O., Russo, R.C., Balzuweit, K., Chiarini-Garcia, H., Castro, A.C.S., Rizzo, E. \& Corrêa Jr, J.D. (2011). Functional dissimilarity of melanomacrophage centres in the liver and spleen from females of the teleost fish Prochilodus argenteus. Cell Tissue Research, 346: 417-425. doi:10.1007/s00441-011-1286-3.
Rodrigues, A.P.O., Pauletti, P., Kindlein, L., Delgado, E.F., Cyrino, J.E.P. \& Machado-Neto, R. (2010). Intestinal histomorphology in Pseudoplatystoma fasciatum fed bovine colostrum as source of protein and bioactive peptides. Scienta Agricola, 67(5): 524-530. doi: 10.1590/S0103-90162010000500005

Sakthivel, M., Deivasigamani, B., Kumaran, S., Bal, S., Bamurugan, S. \& Rajasekar, T. (2012). Seasonal variation in immune organs and immune response of catfish Arius maculatus in Parangipettai coastal area. Journal of Chemical and Pharmaceutical Research, 4(7): 3342-3348.

Satizabal, L.D. (2013). Melano-macrophage characterization and their possible role in the goldfish (Carassius auratus) antibody affinity maturation. Master of Science Thesis, University of Alberta Department of Biological Science, Canada, $121 \mathrm{p}$

Satizabal, L.D. \& Magor, B.G. (2015). Isolation and cytochemical characterization of melanomacrophages and melanomacrophage clusters from goldfish (Carassius auratus, L.). Developmental and Comparative Immunology, 48: 221-228. doi: 10.1016/j.dci.2014.10.003 0145-305X.

Schwindt, A.R., Truelove, N., Schreck, C.B., Fournie, J.W., Landers, D.H. \& Kent, M.L. (2006). Quantitative evaluation of macrophage aggregates in brook trout Salvelinus fontinalis and rainbow trout Oncorhynchus mykiss. Diseases of Aquatic Organisms, 68: 101-113.

Solano, F. (2014). Melanins: Skin Pigments and Much More-Types, Structura Models, Biological Functions, and Formation Routes. New Journal of Science, 498276: 28. doi: 10.1155/2014/498276

Stentiford, G.D., Longshaw, M., Plyons, B., Jones, G., Green, M. \& Feist, S.W. (2003). Histopathological biomarkers in estuarine fish species for the assessment of biological effects of contaminants. Marine Environmental Research, 55: 137-159. doi: 10.1016/S0141-1136(02)00212-X.

Sures, B. (2008). Environmental parasitology interactions between parasites and pollutants in the aquatic environment. Parasite, 15: 434-438.

Suresh, N. (2009). Effect of cadmium chloride on liver, spleen and kidney melanomacrophage centres in Tilapia mossambica. Journal of Environmental Biology, 30 (4): 505-508.

Timur, G., Yardımcı, R.E., Ürkü, Ç. \& Çanak, Ö. (2011). Diagnosis of lactococcosis by bacteriological and histopathological methods in farmed rainbow trout (Oncorhynchus mykiss, L.) at the Marmara region (in Turkish with English abstract). Istanbul Üniversitesi Su Ürünleri Fakültesi Dergisi, 26: 63-81.

Uribe, C., Folch, H., Enriquez, R \& Moran, G. (2011). Innate and adaptive immunity in teleost fish: a review. Veterinarni Medicina, 56 (10): 486-503.

Van der Oost, R., Beyer, J. \& Vermeulen, N.P.E. (2003). Fish bioaccumulation and biomarkers in environmental risk assessment: a review. Environmental Toxicology and Pharmacology, 13: 57-/149. doi: 10.1016/S1382-6689(02)00126-6.

Velkova-Jordanoska, L., Kostoski, G. \& Jordanoska, B. (2008). Antioxidative enzymes in fish as biochemical indicators of aquatic pollution. Bulgarian Journal of Agricultural Science, 14(2): 235-237.

Verburg-Van Kemenade, L.B.M., Groeneveld, A., Van Rens, B.T.T.M. \& Rombout, J. H. W.M. (1994). Characterization of macrophages and neutrophilic granulocytes from the pronephros of carp (Cyprinus carpio). Journal of Experimental Biology., 187: 143-158.

Whyte, S.K. (2007). The innate immune response of finfish - A review of current knowledge. Fish and Shellfish Immunology, 23(6): 1127-1151.

Wolke, R.E., Murchelano, R.A., Dickstein, C.D. \& George, C.J. (1985). Preliminary evaluation of the use of macrophage aggregates (MA) as fish health monitors. Bulletin of Environmental and Contamination and Toxicology, 35: 222-227. doi:10.1007/BF01636502.

Yin, D. (1996). Biochemical basis of lipofuscin, ceroid, and age pigment-like fluorophores. Free Radical Biology and Medicine, 21(6): 871-888.

Zapata, A., Diez, B., Cejalvo, T., Gutierrez-de Frias, C. \& Corte, A. (2006). Ontogeny of the immune system of fish. Fish and Shellfish Immunology, 20:126-136. 